\title{
Necrotizing Pneumonia pada Anak
}

Heda Melinda Nataprawira, Vanda Elfira, ${ }^{*}$ Sang Ayu Kompiyang Indriyani, ${ }^{* *}$ Ery Olivianto**

"Departemen Ilmu Kesehatan Anak Fakultas Kedokteran Universitas Padjajaran/RS Dr Hasan Sadikin Bandung, ${ }^{* *}$ Universitas Mataram/ RSUD Provinsi NTB, ${ }^{* * *}$ Universitas Brawijaya/RSUD Dr Saiful Anwar, Malang

Pneumonia merupakan penyakit dengan angka morbiditas dan mortalitas tinggi pada anak usia di bawah 5 tahun, terutama negara berkembang. Necrotizing pneumonia (NP) merupakan komplikasi yang jarang dan berat dari community acquired pneumonia (CAP). Destruksi parenkim paru normal disertai nekrosis multipel, abses, kavitas atau pneumatokel sebagai akibat oklusi trombotik kapiler alveolus di area konsolidasi terjadi pada NP. Pneumonia yang dalam perjalanannya terlihat lebih sesak, respon yang tidak adekuat dengan antibiotik konvensional, demam yang menetap dapat diperkirakan terjadi NP. Diagnosis ditegakkan dengan CT-scan toraks dengan kontras. Komplikasi berupa fistula bronkopleura, empiema, dan abses paru. Sari Pediatri 2017;19(2):114-8

Kata kunci: necrotizing pneumonia, pneumatokel, anak

\section{Necrotizing Pneumonia in Children}

Heda Melinda Nataprawira, Vanda Elfira, ${ }^{*}$ Sang Ayu Kompiyang Indriyani, ${ }^{* *}$ Ery Olivianto**

Pneumonia causes high morbidity and mortality in children younger than 5 years old, particularly in developing countries. Necrotizing pneumonia (NP) is a rare dan severe complication of community-acquired pneumonia (CAP). Pathologic features of NP characterized by destruction of normal lung parenchyma with multiple necrosis, abscess, cavities, or pneumatocele, caused by thrombotic occlusion of alveolar capillaries in consolidation area. Clinical and/or radiographic signs of a non-responding or progressive pneumonia despite receiving appropriate antibiotic therapy are suggestive for NP, and chest CT scan with contrast is indicated. Bronchopleural fistule, empyema and lung abscess, can be found as complications. Sari Pediatri 2017;19(2):114-8

Keywords : necrotizing pneumonia, pneumatocele, children

Alamat korespondensi: Prof. Dr. dr. Heda Melinda Nataprawira, Sp.A(K), M.Kes. Divisi Respirologi Bagian Ilmu Kesehatan Anak FK UNPAD/ RS Dr Hasan Sadikin Bandung. E-mail: heda_1155@yahoo.com 
$N$ crotizing pneumonia (NP) merupakan salah satu komplikasi berat dari community acquired pneumonia (CAP), ${ }^{1}$ terjadi akibat destruksi parenkim paru normal disertai nekrosis multipel, abses, kavitas atau pneumatokel yang berisi cairan atau udara dan seringkali disertai dengan keterlibatan pleura, apabila mengenai seluruh lobus paru maka akan terjadi gangren. ${ }^{2-7}$ Walaupun patofisiologi NP belum jelas, diperkirakan dengan proses yang dimulai dari invasi bakteri pada pasien yang rentan dengan satu atau beberapa faktor risiko, seperti respons imun yang tidak adekuat, inokulasi yang masif dan virulensi dari bakteri. ${ }^{8}$ Necrotizing pneumonia dengan pembentukan pneumatokel pada pasien dewasa paling banyak disebabkan oleh Staphylococcus aureus, tetapi laporan kasus pada anak paling banyak disebabkan oleh Streptococcus pneumonia.?

Sebagian besar NP pada anak adalah laporan kasus walaupun ada sebagian kecil kajian pustaka. ${ }^{3}$ Kasus NP pertama kali dilaporkan oleh Kerem dkk ${ }^{10}$ (1994) dengan 4 kasus anak. Beberapa penelitian di rumah sakit di Amerika Serikat dan Taiwan dilaporkan terjadi peningkatan insidens NP. ${ }^{11,12}$

Di Indonesia, data mengenai NP tidak ada dan hal ini kemungkinan terkait dengan tidak tercantumnya kelainan ini pada ICD 10, demikian juga belum ada laporan kasus NP. Kajian artikel ini akan membahas etiologi, faktor risiko, patogenesis, gambaran klinis, tata laksana, komplikasi dan prognosis NP pada anak.

\section{Etiologi}

Penyebab tersering dari NP adalah infeksi bakteri, terutama Streptococcus pneumoniae dan Staphylococcus aureus. ${ }^{3}$ Sejak adanya vaksinasi 7 polyvalent pneumococcal conjugate vaccine (PCV-7), maka serotipe dari Streptococcus pneumonia yang banyak menyebabkan NP adalah serotipe non $P C V-7$ termasuk serotipe 3 dan diikuti dengan 19A. ${ }^{3}$ Penelitian Bender $\mathrm{dkk}^{11}$ di Amerika Serikat dan Shen $\mathrm{dkk}^{12}$ di Taiwan menunjukkan peningkatan Streptococcus pneumoniae serotipe 3 sebagai penyebab pneumonia setelah adanya vaksin PCV-7.Vaksin PCV-10 terdiri dari dari serotipe 1, 4, 5, 6B, 7F, 9V, 14, 18C, 19F, dan 23F, diperkenalkan di Taiwan pada tahun 2010. Meskipun vaksin PCV-10 dapat memproduksi proteksi silang terhadap serotipe
19A dengan menginduksi aktivitas opsonofagositik, serotipe 3 tetap tidak dilindungi oleh PCV-10. ${ }^{12}$ Vaksin PCV-13 terdiri dari serotipe 1, 3, 4, 5, 6A, 6B, 7F, 9V, 14, 18C, 19A, 19F dan 23F, namun belum ada laporan mengenai insidens NP setelah adanya vaksin PCV-13. ${ }^{2}$

Bakteri kedua tersering penyebab NP adalah Staphylococcus aureus, terutama community acquired methicillin resistant Staphylococcus aureus (CA-MRSA) yang menghasilkan eksotoksin Panton-Valentine leukocidin (PVL). ${ }^{2,3}$ Panton-Valentine leukocidin sebagai mediator nekrosis jaringan, namun pada beberapa penelitian lain melaporkan $\alpha$-hemolysin dan sitotoksin lainnya juga menyebabkan NP. ${ }^{5}$

Organisme lain yang dapat menyebabkan NP, antara lain, Mycoplasma pneumoniae, Klebsiella pneumoniae, Staphylococcus epidermidis, Eschericia coli, Acitenobacter baumannii, Haemophilus influenzae, Pseudomonas aeruginosa, adenovirus, Streptokokus grup A, koinfeksi dengan virus influenza H1N1, dan bakteri penyebab yang jarang seperti Acitenobacter species dan Mycoplasma hominis. ${ }^{2,5}$

Penyebab tersering non-infeksi adalah aspirasi makanan yang disertai dengan komplikasi sekunder dengan bakteri. ${ }^{2}$ Penyebab lain adalah obat kemoterapi seperti bleomisin, siklofosfamid, penyakit Crohn's, graft versus host disease, inhalasi bahan kimia (hidrokarbon, kerosin, terpentin), inhalasi benda asing, sindrom aspirasi mekonium, psoriasis, penyakit sickle cell, inhalasi asap rokok, toxic shock syndrome, lupus eritematosus sistemik, Wegener's granulomatosis dan vaskulitis nekrotikans lainnya. ${ }^{2}$

\section{Faktor risiko}

Hsieh dkk melakukan penelitian retrospektif untuk mempelajari faktor risiko yang berhubungan dengan komplikasi NP dan empiema pada pneumonia pneumokokus. Dari 71 kasus dengan pneumonia pneumokokus, 40 kasus berkembang menjadi nekrosis parenkim atau empiema. Peneliti mendapatkan 3 faktor risiko berhubungan dengan komplikasi pneumonia yaitu adanya polymorphonuclear (PMN) imatur pada darah tepi, $C$-reactive protein $(\mathrm{CRP})>12$ $\mathrm{mg} / \mathrm{dL}$, dan tidak adanya penyakit penyerta. ${ }^{13}$ Faktor risiko tersebut mendukung pernyataan bahwa respon inflamasi terhadap patogen yang ditandai dengan neutrofilia dengan pergeseran ke kiri dan peningkatan 
CRP, merupakan kunci utama terjadinya cedera jaringan. Hal ini mendukung kesimpulan bahwa NP terjadi karena sitokin-sitokin respons imun yang berlebihan terhadap patogen sehingga menyebabkan destruksi parenkim. ${ }^{13}$

\section{Patogenesis}

Sampai saat ini, patogenesis dari NP masih belum jelas. Oklusi trombotik yang terjadi pada kapiler alveolus di area konsolidasi dan inflamasi dapat menyebabkan iskemi dan nekrosis pada parenkim paru. ${ }^{6,8}$ Obstruksi aliran darah pada bronkus proksimal membuat antibiotik sulit menjangkau area yang terinfeksi sehingga menyebabkan destruksi progresif dan hilangnya struktur lobus paru, diikuti dengan septikemia, dan terjadinya fistula bronkopleura. ${ }^{8}$

Staphylococcus aureus mensekresi eksotoksin PVL, menyebabkan ulserasi nekrotik luas pada mukosa trakea dan bronkial, dan nekrosis hemoragik pada septum interalveolar yang didapatkan pada penelitian post-mortem. Panton-Valentine Leucocidin mempunyai dua komponen yaitu LukS-PV dan LukF-PV yang dapat menyebabkan sitolisis dari sel. Konsentrasi $P V L$ yang tinggi menyebabkan sitolisis dan aktivasi sitokin inflamasi yang menyebabkan nekrosis jaringan, sedangkan konsentrasi $P V L$ yang rendah menyebabkan apoptosis dari sel. ${ }^{3,14}$

Masih belum jelas bagaimana Streptococcus pneumonia dapat menyebabkan kerusakan jaringan. Streptococcus pneumonia memproduksi eksotoksin yang menyebabkan kerusakan walaupun telah dilakukan eradikasi infeksi. ${ }^{15}$ Toksin ini diduga yang menyebabkan terjadinya nekrosis paru. Segmen paru yang nekrosis ini kemudian berubah menjadi pneumatokel. 3,14

\section{Gambaran klinis}

Secara umum, gambaran klinis NP sama dengan pneumonia tanpa komplikasi. Perbedaan utama adalah pasien terlihat lebih sakit dan respon yang tidak adekuat terhadap terapi antibiotik konvensional. Anak mengalami sesak berkepanjangan, demam yang menetap, batuk, nyeri dada, takikardia, hipoksia, dan perfusi perifer yang buruk. ${ }^{2,5}$

Pada kasus dengan PVL positive staphylococcal necrotizing pneumonia memiliki gambaran klinis demam tinggi $\left(>39^{\circ} \mathrm{C}\right)$, hemoptisis, efusi pleura, distres pernafasan akut, dahak yang purulen, dan leukopenia dibandingkan dengan non-PVL staphylococcal necrotizing pneumonia. Riwayat infeksi dengan Staphylococcus aureus pada pasien maupun keluarga dekat seringkali ditemukan pada beberapa kasus. Panton Valentine Leukocidin-positive staphylococcal necrotizing pneumonia juga dapat menyebabkan purpura fulminan. ${ }^{2,16,17}$

\section{Diagnosis}

Kuman penyebab pneumonia yang berat dan progresif sangat penting diketahui sebagai dasar pemberian antibiotik, meskipun hasil kultur tidak selalu positif. Hasil kultur darah tepi, cairan pleura dan jaringan paru yang terinfeksi, juga dapat memberikan hasil yang dapat digunakan untuk mengetahui bakteri penyebab NP. ${ }^{5}$ Pada pemeriksaan laboratorium didapatkan leukositosis, CRP yang tinggi, adanya PMN imatur pada darah tepi. ${ }^{5,6,13}$

Diagnosis NP ditegakkan berdasarkan gambaran radiologi dengan melakukan radiografi serial dan CT-scan dengan kontras. Pada fase awal pneumonia, gambaran foto toraks berupa konsolidasi. Foto toraks ulang dilakukan setiap 3-4 hari untuk evaluasi terapi antibiotik dan komplikasi. Pada NP foto toraks menunjukkan gambaran kavitas multipel dengan latar belakang konsolidasi (Gambar 1a, 2a). Gambaran kavitas juga dapat ditemukan pada CT-scan toraks (Gambar 1b, 2b). ${ }^{2,6}$ CT-scan dengan kontras merupakan prosedur standar untuk menegakkan diagnosis NP dan sangat membantu untuk melihat komplikasi parenkim yang tidak terlihat pada foto toraks. Indikasi CT-scan toraks dilakukan jika pada gambaran foto toraks menunjukkan pneumonia yang progresif, efusi pleura atau hidropneumotoraks, atau jika secara klinis didapatkan hemoptisis, distres pernafasan dan syok septik walaupun sudah mendapatkan antibiotik yang adekuat. Temuan berupa konsolidasi dengan area nekrosis multipel, menunjukkan sugestif NP. ${ }^{5}$ Pemeriksaan CT-scan toraks sangat penting untuk menghindari keterlambatan diagnosis NP. Penelitian Hodina $\mathrm{dkk}^{18}$ membandingkan pemeriksaan CT-scan dan foto toraks pada 30 anak, dan mendapatkan adanya keterlambatan 5-9 hari deteksi dari nekrosis kavitas pada 3 dari 9 anak. 

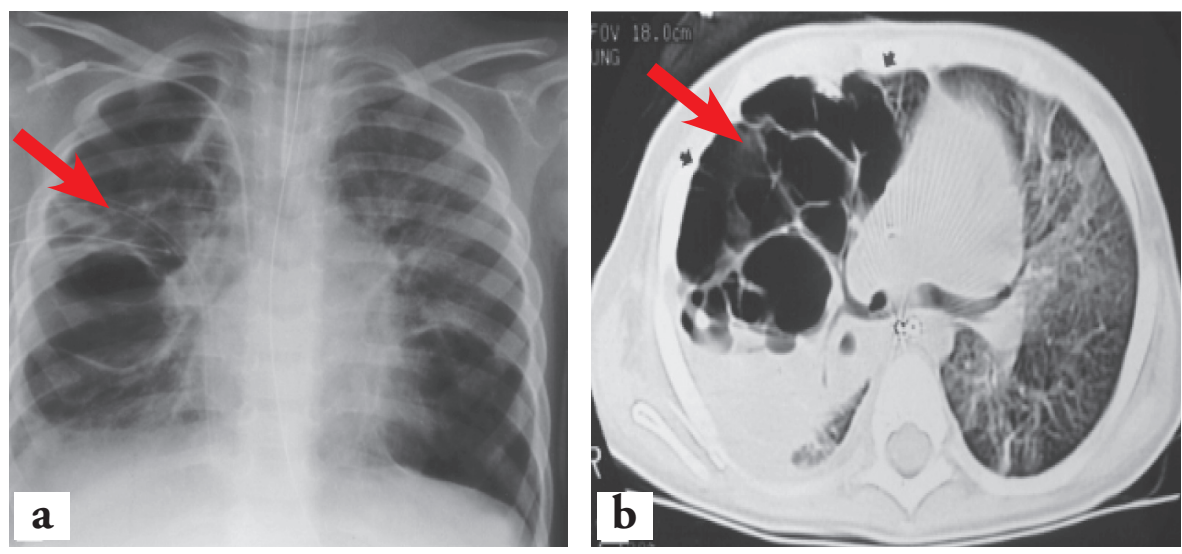

Gambar 1. (a) Gambaran foto toraks anak perempuan usia 2 tahun dengan pneumonia pneumokokus bilateral, didapatkan 3-4 kavitas pada paru kanan (tanda panah), (b) Gambaran CT scan toraks potongan aksial pada pasien yang sama, menunjukkan kavitas multipel berdinding tipis pada segmen apikal dan anterior lobus kanan atas, segmen posterior terdapat konsolidasi dengan kavitas multipel (tanda panah). dengan multipel kavitas. Sumber : Hodina $\mathrm{dkk}^{18}$
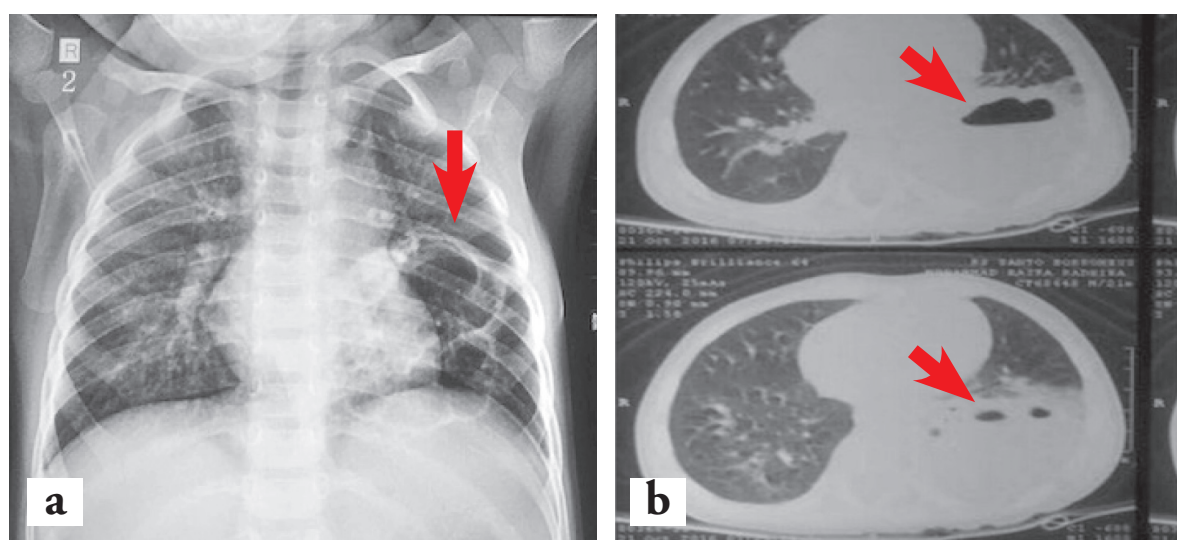

Gambar 2.(a) gambaran foto toraks dengan kavitas (tanda panah), (b) Gambaran CT scan toraks pada pasien yang sama (tanda panah). Sumber : koleksi pribadi

\section{Tata laksana}

Tata laksana NP adalah mengobati pneumonia dan komplikasi pneumonia yang terjadi. Tata laksana umum berupa pemberian oksigen, cairan, nutrisi, dan terapi simptomatik. Belum ada rekomendasi penelitian berbasis bukti untuk jenis dan lama pemberian antibiotik. 2,19

Antibiotik yang direkomendasikan berdasarkan panduan di Inggris adalah linezolid atau klindamisin sebagai standar terapi empiris. Apabila terjadi perburukan diberikan terapi tambahan dengan intravenous immunoglobulin (IVIG) dengan dosis 1 gram $/ \mathrm{kgBB}$ dapat diulang dalam 24-48 jam. ${ }^{19}$ Apabila diduga penyebab Staphylococcus aureus pemberian kloksasilin dapat dipertimbangkan.

\section{Komplikasi}

Komplikasi yang sering terjadi pada NP berupa efusi parapneumonia dan empiema. Komplikasi lebih lanjut dapat terjadi fistula bronkopleura, hemoptisis masif dan pneumonia difus bilateral, syok septik, dan gagal nafas. ${ }^{5}$ Penelitian Krenke $\mathrm{dkk}^{20}$ menunjukkan komplikasi $N P$ berupa efusi parapneumonia atau empiema ( $97 \%)$, fistula bronkopleura (25\%), dan pneumotoraks (6,25\%).

\section{Prognosis}

Prognosis dari NP biasanya baik dengan mortalitas yang rendah dan morbiditas minimal. Pada dua penelitian di 
Taiwan dengan 36-40 anak dilaporkan mortalitas berkisar antara 5,5-7,5\%. Penyebab kematian tidak disebutkan pada kedua penelitian tersebut. ${ }^{3,13}$ Prognosis jangka panjang baik dengan terapi konservatif dengan angka mortalitas 5,5\%. ${ }^{21}$ Penelitian Hsieh $\mathrm{dkk}^{15}$ di Taiwan, evaluasi foto toraks dalam 1-3 bulan menunjukkan resolusi komplit, tetapi terdapat fibrosis minimal. Kavitas foto toraks dapat hilang, sehingga pemeriksaan CT-scan tidak selalu harus diulang pada anak dengan respon klinis yang baik. ${ }^{2}$

\section{Kesimpulan}

Necrotizing pneumonia sebagai salah satu komplikasi pneumonia ditandai dengan klinis demam dan sesak yang terus berlanjut yang tidak responsif dengan terapi antibiotik konvensional dengan faktor risiko antara lain $P M N$ imatur pada darah tepi, $C R P>12 \mathrm{mg} / \mathrm{dL}$ dan tidak ada penyakit penyerta. Necrotizing pneumonia didiagnosis pada pasien pneumonia yang pada evaluasi pencitraan menunjukkan adanya konsolidasi yang berkelanjutan dengan terbentuknya pneumatokel. CT scan toraks sebaiknya dilakukan untuk menghindari kerterlambatan diagnosis NP pada pasien CAP yang tidak responsif terhadap pemberian antibiotik yang adekuat.

Perawatan pasien NP di rumah sakit memerlukan pemberian antibiotik intravena yang lebih lama, dan beberapa kasus membutuhkan intervensi pembedahan. Prognosis NP secara umum baik.

\section{Daftar pustaka}

1. Chatha N, Fortin D, Bosma KJ. Management of necrotizing pneumonia and pulmonary gangrene: a case series and review of the literature. Can Respir J 2014;21:239-45.

2. Spencer DA, Thomas MF. Necrotising pneumonia in children. Paediatr Respir Rev 2014; 15:240-5.

3. Tai DW. Review on paediatric necrotising pneumonia and its pulmonary co-morbidities. J Paediatr Respir Crit Care 2014;10:20-31.

4. Sawicki GS, Lu FL, Valim C, Cleveland RH, Colin AA. Necrotising pneumonia is an increasingly detected complication of pneumonia in children. Eur Respir J 2008;31:1285-91.

5. Tsaia YF, Kub YH. Necrotizing pneumonia: a rare complication of pneumonia requiring special consideration. Curr Opin Pulm Med 2012;18:246-52.

6. Cicak B, Verona E, Stefanovic M. Necrotizing pneumonia in infants. Acta Clin Croat 2010; 49:321-6.
7. Wong KS, Chiu CH, Yeow KM, Huang YC, Liu HP, Lin TY. Necrotising pneumonitis in children. Eur J Pediatr 2000;159:684-8.

8. Westphal FL, de Lima LC, Netto JC, Tavares E, de OlivieraAndrade ED, da Silva MS. Surgical treatment of children with necrotizing pneumonia. J Bras Penumol 2010; 36:716-23.

9. Kosucu P, Ahmetoglu A, Cay A, Imamoglu M, Ozdemir O, Dinac H. Computed tomography in evaluation of cavity necrosis in complicated childhood pneumonia. Australia Radiol 2004;48:318-23.

10. Kerem E, Ziv YB, Rudenski B, Katz S, Kieid D, Branski D. Bacteremic necrotizing pneumococcal pneumonia in children. Am J Respir Crit Care Med 1994;149:242-4.

11. Bender JM, Ampofo K, Korgenski K, Byington CL. Pneumococcal necrotizing pneumonia in Utah: does serotype matter? Clin Infect Dis 2008;46:1-12.

12. Shen CF, Wang SM, Lee KH, Ho TS, Liu CC. Childhood invasive pneumococcal disease caused by non-7-valent pneumococcal vaccine (PCV7) serotypes under partial immunization in Taiwan. J Formosan Med Assoc 2013; 112:561-8.

13. Hsieh YC, Hsueh PR, Lu CY, Lee PI, Lee CY, Huang LM. Clinical manifestations and molecular epidemiology of necrotizing pneumonia and empyema caused by Streptococcus pneumoniae in children in Taiwan. Clin Infect Dis 2004;38:830-5.

14. Fujisaki N, Nakao A, Okamoto A, Nishimura T, Kotani J. Clinical feature: community acquired pneumonia caused by Panton-Valentine leukocidin positive Staphylococcus aureus. J Intensive Crit Care 2016;2:1-5.

15. Hsieh YC, Hsiao CH, Tsao PN, Huang LM. Necrotizing pneumococcal pneumonia in children: The role of pulmonary gangrene. Pediatr Pulmonol 2006;41:623-9.

16. Hoffer FA, Bloom DA, Colin AA, Fishman SJ. Lung abscess versus necrotizing pneumonia: implications for interventional therapy. Pediatr Radiol 1999;29:87-91.

17. Schwartz KL, Nourse C. Panton-Valentine leukocidinassociated Staphylococcus aureus necrotizing pneumonia in infants: a report of four cases and review of the literature. Eur J Pediatr 2012;171:711-7.

18. Hodina M, Hanquinet S, Cotting J, Schynder P, Gudinchet F. Imaging of cavitary necrosis in complicated childhood pneumonia. Eur Radiol 2002; 12:391-6.

19. Harris M, Clark J, Coote N, Thomson A. British thoracic society guidelines for the management of community acquired pneumonia in children: update 2011. Thorax 2011; 66 Suppl 2;S1-23.

20. Krenke K, Sanocki M, Urbankowska E, Kulus M. Necrotizing pneumonia and its complications in children. Adv Exp Med Biol 2015;12:9-17.

21. Pabary R, Balfour-Lynn IM. Complicated pneumonia in children. Breathe 2013;9:211-20. 